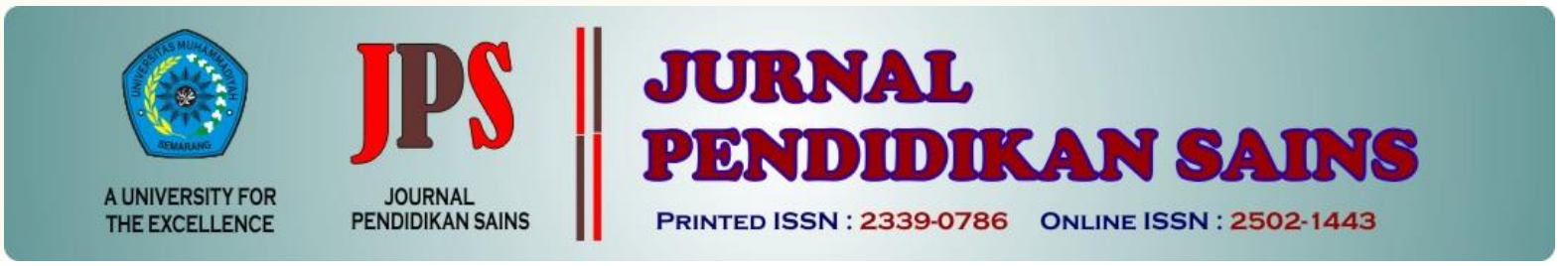

\title{
PENGALAMAN CALON GURU SAINS DALAM PEMBELAJARAN DARING SELAMA MASA PANDEMI COVID-19
}

\author{
Oleh: \\ Nur Eka Kusuma Hindrasti ${ }^{1 *}$, Ardi Widhia Sabekti ${ }^{2}$ \\ ${ }^{1}$ Program Studi Pendidikan Biologi, Universitas Maritim Raja Ali Haji (UMRAH), Indonesia \\ ${ }^{2}$ Program Studi pendidikan kimia, Universitas Maritim Raja Ali Haji (UMRAH), Indonesia \\ Jl. Politeknik Senggarang, Tanjungpinang, Kepulauan Riau
}

\begin{tabular}{|c|c|}
\hline Article history & Abstract \\
\hline Submission $: 2020-08-01$ & \multirow{5}{*}{$\begin{array}{l}\text { This study aims to determine the experience of preservice science } \\
\text { teacher in online learning during the Covid- } 19 \text { pandemic in } \\
\text { Tanjungpinang. This research is a survey research, with a quantitative } \\
\text { descriptive research method. The sample is determined using total } \\
\text { sampling technique, with totaling } 164 \text { respondents. The research } \\
\text { instrument used a questionnaire in the Google Form. The results } \\
\text { showed that almost all preservice science teacher took part in online } \\
\text { learning from home using smartphone devices and learning platforms } \\
\text { in the form of whatsapp and google classroom, as well as video } \\
\text { conferencing, namely zoom. Most preservice science teacher still do } \\
\text { practicums that are carried out independently at home and also } \\
\text { virtually. Limited networks and internet data packages are two major } \\
\text { aspects that interfere with online learning. However, preservice science } \\
\text { teacher feel the benefits of online learning, among others, being } \\
\text { efficient in terms of time, increasing digital technology literacy, and } \\
\text { avoiding Covid-19. }\end{array}$} \\
\hline : 2020-09-16 & \\
\hline : 2020-09-23 & \\
\hline Keyword: & \\
\hline $\begin{array}{l}\text { Kata kunci: experience; } \\
\text { preservice science teacher; } \\
\text { online learning }\end{array}$ & \\
\hline
\end{tabular}

\section{Pendahuluan}

Covid-19 (Corona Virus Disease 2019) ditetapkan oleh WHO (World Health Organization) sebagai suatu penyakit menular yang disebabkan oleh corona virus yang paling baru ditemukan. Coronavirus adalah keluarga besar virus yang dapat menyebabkan penyakit pada hewan atau manusia. Pada manusia, beberapa coronavirus diketahui menyebabkan infeksi pernafasan mulai dari flu biasa hingga penyakit yang lebih parah seperti Middle East Respiratory Syndrome (MERS) dan Severe Acute Respiratory Syndrome (SARS). Virus dan penyakit baru ini tidak diketahui sebelum wabah dimulai di Wuhan, Cina, pada Desember 2019. COVID-19 menjalar dengan cepat hingga ke negara-negara di seluruh dunia dalam jangka beberapa minggu (Hermansyah, 2020). Sejak 11 Maret 2020 WHO menetapkan Covid-19 sebagai pandemi yang menyerang banyak negara secara global. Data terkahir (15 Juni 2020) dari WHO menunjukkan dari 216 negara dengan kasus covid-19, sebanyak 7.690.708 orang terkonfirmasi positif dan 427.630 orang telah meninggal dunia (World Health Organization (WHO), 2020)

Di Indonesia, Covid-19 juga sudah semakin mewabah dengan tajamnya peningkatan jumlah kasus pasien terinfeksi, pasien dalam pengawasan, dan orang dalam pemantauan setiap hari. Pemerintah menetapkan kedaruratan kesehatan masyarakat

\footnotetext{
*Corresponding Author:

Nama : Nur Eka Kusuma Hindrasti

Lembaga : Universitas Maritim Raja Ali Haji

Email : nurekakh2017@umrah.ac.id
} 
melalui Keputusan Presiden Nomor 11 Tahun 2020 tentang Penetapan Kedaruaratan Kesehatan Masyarakat terhadap Corona Virus Disease 2019 (Covid-19), serta keputusan Presiden Nomor 12 Tahun 2020 tentang Penetapan Bencana Non alam Penyebaran Corona Virus Disease 2019 (Covid-19) sebagai bencana nasional.

Pandemi Covid-19 merupakan masalah bidang kesehatan yang berdampak pada segala bidang, termasuk bidang pendidikan. Untuk itu, Menteri Pendidikan dan Kebudayaan menerbitkan Surat Edaran (SE) Nomor 4 Tahun 2020 tentang Pelaksanaan Pendidikan Ddlam Masa Darurat Corona Virus Disease 2019 (Covid-19) (Kemdikbud, 2020). Dengan adanya SE tersebut terjadi perubahan di bidang pendidikan yang sangat drastis. Perubahan tersebut terjadi di berbagai tingkat pendidikan mencakup seluruh aktivitas yang dilakukan, termasuk aktivitas belajar dan mengajar yang merupakan aktivitas terpenting dalam dunia pendidikan.

Sebelum masa Pandemi Covid-19, teknologi pendidikan berbasis digital di Indonesia sudah mulai berkembang, walaupun belum secanggih negara maju. Adanya pandemi ini teknologi pendidikan berbasis digital berkembang dengan sangat pesat. Pada masa Pandemi Covid-19, aktivitas belajar dan mengajar hampir sepenuhnya bergantung pada teknologi digital, dengan demikian pembelajaran daring (online) menjadi satusatunya solusi. Pembelajaran daring menjadi solusi karena dapat dilakukan di rumah. Dengan pendidik dan peserta didik tetap di rumah, dapat memutus rantai penyebaran virus dan menjaga keamanan dan keselamatan bersama rumah (Zhafira et al., 2020). Perguruan tinggi dianggap tingkat pendidikan yang paling siap dan baik melakukan pembelajaran daring di. Dengan alasan pembelajaran di perguruan tinggi merupakan pembelajaran untuk orang dewasa, sehingga peserta didiknya lebih mandiri dan matang dalam menggunakan teknologi. Selain itu, peserta didik di perguruan tinggi termasuk kaum intelek dan cendekiawan yang lebih cepat dalam membangun ilmu pengetahuan dan teknologi (IPTEK).

Pembelajaran daring memberikan pengalaman yang bermacam-macam bagi pendidik dan peserta didik. Pengalaman pembelajaran daring bagi calon guru memiliki makna yang khusus. Di samping mereka menjadi peserta didik, mereka juga belajar bagaimana mendidik dan mengajar, khususnya di era digital seperti yang terjadi di masa pandemi Covid-19 ini (Farida et al., 2020; Jamaluddin et al., 2020; Zhafira et al., 2020).

Pengalaman pembelajaran bagi calon guru sains, secara umum sama dengan calon guru yang lainnya. Adanya praktikum baik di dalam maupun di luar laboratorium menjadi kharakteristik pembelajaran sains. Selain itu, penerapan pendekatan saintifik juga menjadi ciri pembelajaran sains. Pengalaman mahasiswa dalam pembelajaran daring antara lain terkait aplikasi (Zhafira et al., 2020), tempat, alat elektronik, pemahaman mahasiswa, keinginan untuk melakukan pembelajaran daring seterusnya (Anhusadar, 2020). Penelitian yang mengungkap pengalaman calon guru sains secara khusus belum penulis temukan.

Tanjungpinang termasuk ke dalam zona merah pandemi Covid-19. Data terakhir tertanggal 14 Juni 2020 dari website Gugus Tugas Covid-19 menunjukkan bahwa terdapat 27 kasus positif dan 12 meninggal dunia (Gugus Tugas COVID-19 KEPRI, 2020). Mengingat berakhirnya pandemi Covid-19 tidak dapat dipastikan, maka pembelajaran daring diprediksi masih tetap akan dilakukan di Tanjungpinang minimal satu semester ke depan. UMRAH adalah satu-satunya perguruan tinggi yang memiliki jurusan pendidikan sains meliputi pendidikan biologi dan pendidikan kimia. Jurusan pendidikan fisika dan pendidikan sains terpadu (terintegrasi) belum ada di Tanjungpinang, Sehingga calon guru sains di Tanjungpinang kebanyakan dari dua jurusan tersebut (pendidikan biologi dan pendidikan kimia).

Calon guru sains yang kuliah di UMRAH sebagian besar berasal dari pulaupulau di Kepulauan Riau, seperti Batam, Anambas, Lingga, Karimun, Natuna, dan Bintan. Banyak daerah di pulau-pulau tersebut yang ketersediaan listrik dan jaringan internetnya masih terbatas. Jika selama masa pandemi para calon guru sains pulang kampung ke daerahnya masing-masing, hal ini dimungkinkan akan sangat berpengaruh terhadap pengalaman mereka dalam pembelajaran daring yang diikutinya.

Sebagai langkah awal dalam perancangan pembelajaran, perlu dilakukan analisis kebutuhan, salah satunya terkait pengalaman peserta didik. Pengalaman pembelajaran daring calon guru sains perlu dianalisis, sebagai pertimbangan dalam mengembangkan pembelajaran sains secara daring selanjutnya. Dengan demikian perlu 
dilakukan penelitian untuk mengetahui pengalaman calon guru sains dalam pembelajaran daring selama masa pandemi Covid-19.

\section{Metode Penelitian}

\section{Jenis Penelitian}

Penelitian yang dilakukan merupakan penelitian survei, dengan metode deskriptif kuantitatif.

\section{Waktu dan Tempat Penelitian}

Penelitian dilaksanakan pada 1-11 Juni 2020 dengan subjek penelitian yaitu calon guru sains di Tanjungpinang, yang seluruhnya kuliah di Universitas Maritim Raja Ali Haji (UMRAH). UMRAH adalah satu-satunya perguruan tinggi di Tanjungpinang yang memiliki jurusan Pendidikan Biologi dan Kimia, maka yang dinyatakan sebagai calon guru sains pada penelitian ini adalah mahasiswa yang kuliah di kedua jurusan tersebut.

\section{Subjek Penelitian}

Subjek penelitian yaitu seluruh calon guru sains selain mahasiswa tingkat akhir, yang berjumlah 278 orang. Mahasiswa calon guru sains tingkat akhir tidak dimasukkan ke dalam subjek penelitian karena diasumsikan sebagian besar tidak mengikuti mata kuliah selain skripsi.

\section{Prosedur}

Prosedur penelitian ini sesuai dengan penelitian survei yaitu diawali dengan pengembangan instrumen penelitian berupa kuesioner. Selanjutnya kuesioner diberikan ke seluruh subjek penelitian. Subjek penelitian yang mengisi dan mengumpulkan kuesioner selanjutnya disebut dengan responden. Peneliti hanya mengolah data dari responden tersebut.

Responden pada penelitian ini yaitu 66\% berasal dari Prodi Pendidikan Biologi, dan sisanya berasal dari Prodi Pendidikan Kimia. Berdasarkan jumlah total calon guru di kedua prodi, memang sesuai jika responden lebih banyak berasal dari Prodi Pendidikan Biologi.

\section{Data, Instrumen, dan Teknik Pengumpulan Data}

Data dalam penelitian ini adalah pengalaman calon guru sains dalam mengikuti pembelajaran daring selama pandemi Covid-19. Teknik pengumpulan data yaitu survei. Instrumen yang digunakan untuk mengumpulkan data adalah kuesioner menggunakan google form. Pengumpulan data pada penelitian survei dapat dilakukan dengan google form (Jamaluddin et al., 2020). Google form dibagikan kepada seluruh subjek penelitian, namun yang mengisi dan mengirimkan ke peneliti sebanyak 164 mahasiswa. Selain menggunakan kuesioner dalam bentuk google form, juga dilakukan wawancara kepada beberapa responden untuk mengkonfirmasi jawaban yang dianggap perlu.

Kuesioner terdiri dari 13 aspek dan 18 butir pertanyaan. Kisi-kisi instrumen kuesioner terdapat pada Tabel 1.

Tabel 1. Kisi-kisi Kuesioner Pengalaman Belajar Selama Masa Pandemi

Aspek No Butir Pernyataan

\begin{tabular}{lc}
\hline Keikutsertaan responden mengikuti pembelajaran daring & 1 \\
\hline Tempat responden mengikuti pembelajaran daring & 2 \\
\hline Perangkat yang digunakan dalam pembelajaran daring & 3 \\
\hline Platform yang digunakan dalam pembelajaran daring & 4 \\
\hline Adanya materi pengayaan & 5,6 \\
\hline Format penyampaian materi & 7 \\
\hline Penggunaaan video conference & 8,9 \\
\hline Keinginan mengikuti pembelajaran daring untuk seterusnya & 10,11 \\
\hline Pola komunikasi & 12 \\
\hline Kegiatan praktikum saat masa pandemi & 13 \\
\hline Keterlaksanaan pendekatan saintifik & 14,15 \\
\hline Kendala dan manfaat pembelajaran daring & 16,17 \\
\hline Kesan dan pendapat tentang pembelajaran daring & 18
\end{tabular}

\section{Teknik Analisis Data}

Data yang didapat dipersentasekan,

kemudian dilakukan analisis secara deskriptif. 


\section{Hasil Penelitian dan Pembahasan}

Aspek pertama yaitu keikutsertaan responden mengikuti pembelajaran daring. Sebelum masa pandemi covid-19 keikutsertaan calon guru sains dalam pembelajaran daring ditunjukkan oleh diagram pada Gambar 1.

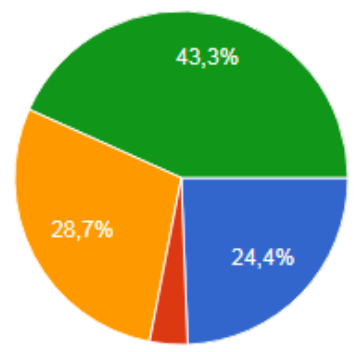

$$
\begin{aligned}
& \text { Selalu } \\
& \text { Sering } \\
& \text { Kadang-kadang } \\
& \text { Tidak pernah }
\end{aligned}
$$

Gambar 1. Keikutsertaan Calon Guru Sains dalam Pembelajaran Daring

Berdasarkan Gambar 1 diketahui bahwa hampir setengah $(43,3 \%)$ calon guru sains tidak pernah mengikuti pembelajaran daring sebelum masa pandemi Covid-19. 28,7\% calon guru sains kadang-kadang mengikuti mengikuti pembelajaran daring sebelum masa pandemi Covid-19. Dengan demikian lebih dari $50 \%$ calon guru sains pernah melakukan pembelajaran secara online, hal ini dapat menjadi pengalaman calon guru dalam mengikuti pembelajaran daring di masa pandemi Covid-19. Pembelajaran daring sebelum masa pandemi Covid-19 dilakukan karena beberapa alasan seperti adanya arahan dari kampus wajib menggunakan platform pembelajaran Syarah pada satu waktu yang ditentukan. Syarah merupakan LMS yang sedang dikembangkan oleh UMRAH. Maka untuk kepentingan pengembangan, ada suatu waktu UMRAH mewajibkan semua mata kuliah menggunakan Syarah. Ini terjadi beberapa kali, namun hampir selalu tidak terlaksana dengan baik karena kendala jaringan dan kuota internet UMRAH terbatas. Masalah jaringan adalah kendala paling besar yang dihadapi peserta pembelajaran daring (Farida et al., 2020; Jamaluddin et al., 2020).

Dengan adanya SE dari Rektor UMRAH yang dibuat berdasarkan SE Mendikbud, maka kuliah dan kerja secara umum wajib dilakukan di rumah. Sejak Maret sampai dengan Juni 2020 SE Rektor tersebut diperpanjang sebanyak 3 kali, dimana SE Rektor terkait darurat Pandemi Covid-19 yang paling terbaru adalah SE Rektor mengenai Sistem Kerja Pegawai dala Tatanan Normal Baru (UMRAH, 2020). Kuliah dan Kerja dari Rumah (KKR) dilakukan untuk menghindari penyebaran Covid-19. Tentu saja hal ini menjadi pengalaman baru bagi pendidik, peserta didik, dan juga calon guru.

Aspek ke-2 yaitu tempat responden mengikuti pembelajaran daring. Keikutsertaan calon guru sains pada pembelajaran daring terkait tempat ditunjukkan pada Gambar 2.

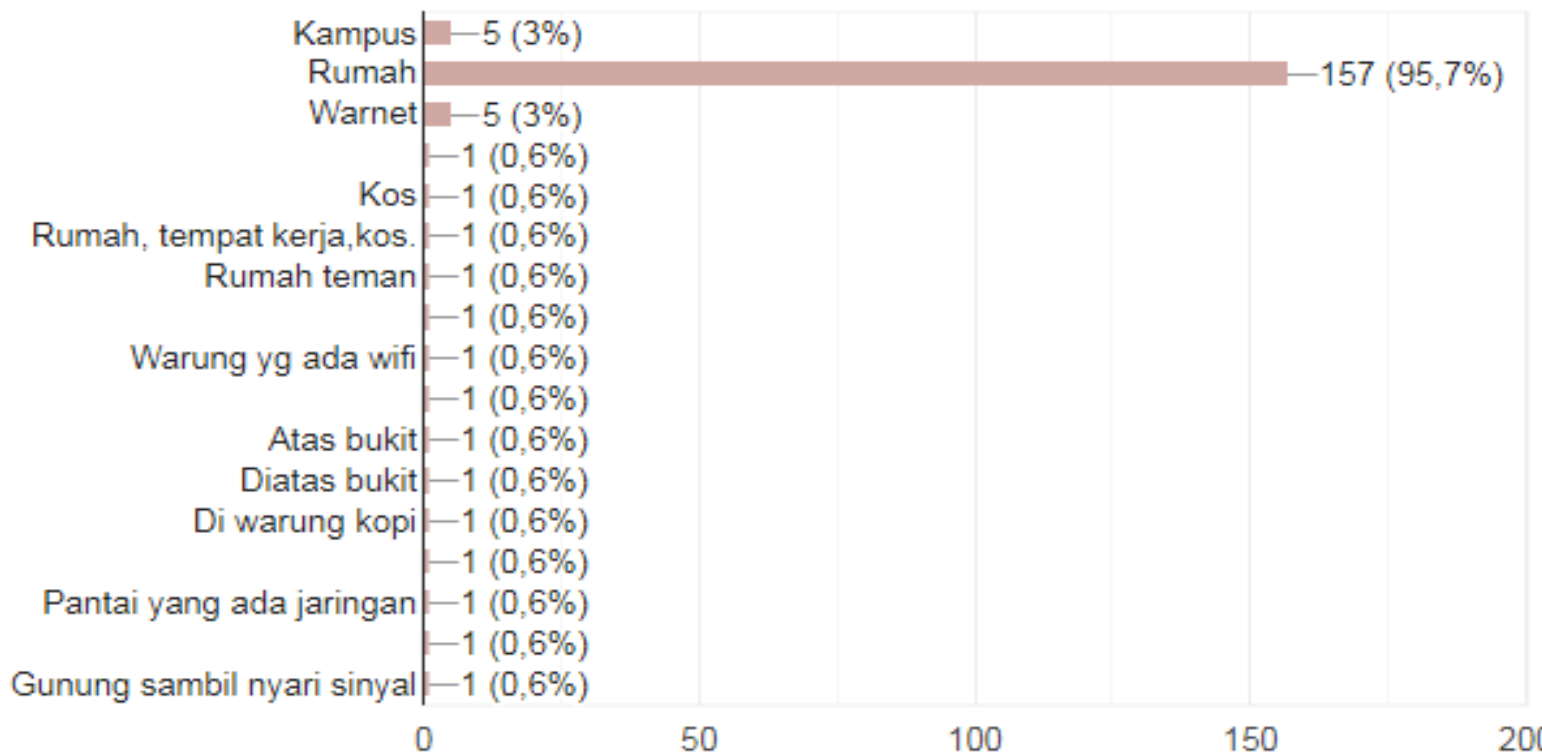

Gambar 2. Tempat Calon Guru Sains Mengikuti Pembelajaran Daring

Berdasarkan Gambar 2 diketahui bahwa hampir seluruh (96\%) calon guru sains mengikuti pembelajaran daring dari rumah.
Hampir seluruh calon guru pulang ke daerah asalnya masing-masing, walaupun ada himbauan dari universitas agar tidak 
meninggalkan daerah tempat belajar (Tanjungpinang). Alasan calon guru pulang ke daerahnya masing-masing antara lain daerah asal tidak termasuk ke dalam zona merah, tinggal bersama keluarga di masa Pandemi Covid-19 dianggap lebih aman dan nyaman, dan tidak adanya kepastian berakhirnya pembelajaran daring. Karena sebagian besar daerah asal calon guru sains adalah kepulauan maka ada daerah yang masih terkendala jaringan dan listrik, sehingga mereka mengikuti kuliah daerah yang ada jaringan, seperti pantai, bukit, warnet, rumah tetangga, dan warung kopi. Jaringan internet di luar jawa memang lebih terbatas dibanding di jawa. Seperti halnya penelitian oleh Anhusadar (2020) di Sulawesi Tenggara, menyatakan bahwa $11 \%$ mahasiswa yang menjadi responden melakukan kuliah online di kebun dan rumah tetangga.

Aspek ke-3 yaitu Perangkat yang digunakan dalam pembelajaran daring. Perangkat yang digunakan mahasiswa dalam mengikuti pembelajaran daring memberikan pengalaman baru yang berdampak pada kehidupan mereka. Perangkat yang digunakan oleh calon guru sains untuk mengikuti pembelajaran daring ditunjukkan oleh Gambar 3.

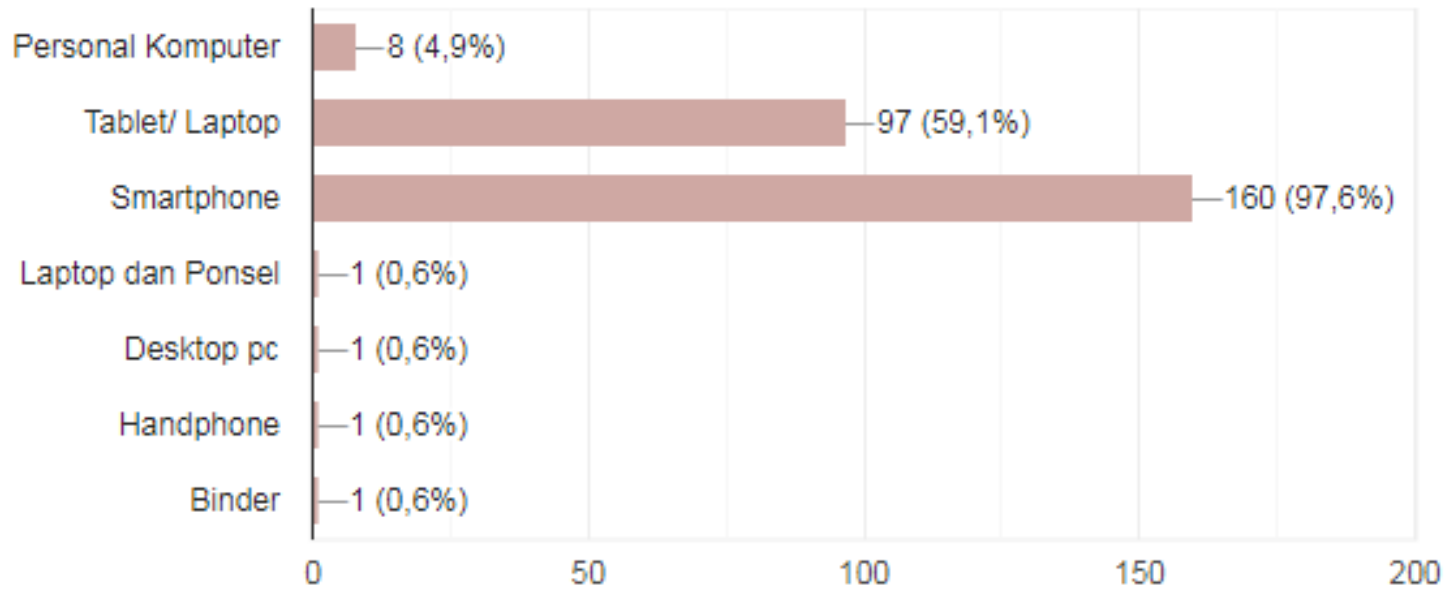

Gambar 3. Perangkat yang Digunakan oleh Calon Guru Sains untuk Mengikuti Pembelajaran Daring

Berdasarkan Gambar 3 diketahui bahwa smartphone digunakan dalam mengikuti pembelajaran daring oleh hampir seluruh calon guru $(97,6 \%)$. Laptop digunakan oleh $60 \%$ calon guru dan hanya $5 \%$ calon guru yang menggunakan personal computer. Smartphone merupakan kebutuhan primer di era digital saat ini, hampir semua orang memiliki smartphoone, bahkan satu orang memiliki lebih dari satu smartphone. Dengan demikian pembelajaran daring dapat dilakukan dengan mudah dan praktis karena peserta didik sudah biasa menggunakan Smartphone. Penelitian Anhusadar (2020), juga menunjukkan hal yang sama, sebanyak $96,6 \%$ mahasiswa menggunakan HP untuk kuliah online. Penggunaan Smartphone bukan menjadi kendala dalam melakukan daring, yang lebih menjadi kendala adalah penggunaan aplikasi/platform pembelajaran. Ada mahasiswa yang belum familiar dengan platform pembelajaran tertentu.

Platform pembelajaran daring sudah banyak dikembangkan, seperti Google Classroom (Kumar \& Bervell, 2019; Dash,
2019; Rahmad et al., 2019), Edmodo (David \& Whittam, 2008; Zainudin \& Pambudi, 2019), Moodle (Didik et al., 2020; Ngibad et al., 2020; Mpungose, 2020; Khoir et al., 2020), Massive Open Onlie Course (MOOC) (Onah \& Sinclair, 2017; de Jong et al., 2020; Lemay \& Doleck, 2020). Whatsapp sebenarnya bukan platform pembelajaran, namun demikian banyak yang mengembangkannya sebagai platform pembelajaran ((Baguma et al., 2019; Nagaletchimee, 2015; Rahaded et al., 2020). Selain whatsapp, platform chatting lainnya yang digunakan sebagai media pembelajaran daring adalah Telegram. Namun, pembelajaran bahasa yang sering menggunakan Telegram untuk membantu pembelajarannya (Faramarzi et al., 2019; Mahzoun \& Zohoorian, 2019). Selain platform yang dikembangkan oleh programmer (pengembang program), platform pembelajaran juga dikembangkan oleh masingmasing kampus, seperti E-knows (Farida et al., 2020; Jamaluddin et al., 2020; Zhafira et al., 2020), dan Syarah yang dikembangkan oleh UMRAH. 
Aspek yang ke-4 yaitu platform yang digunakan oleh calon guru sains dalam mengikuti pembelajaran daring, ditunjukkan oleh Gambar 4.

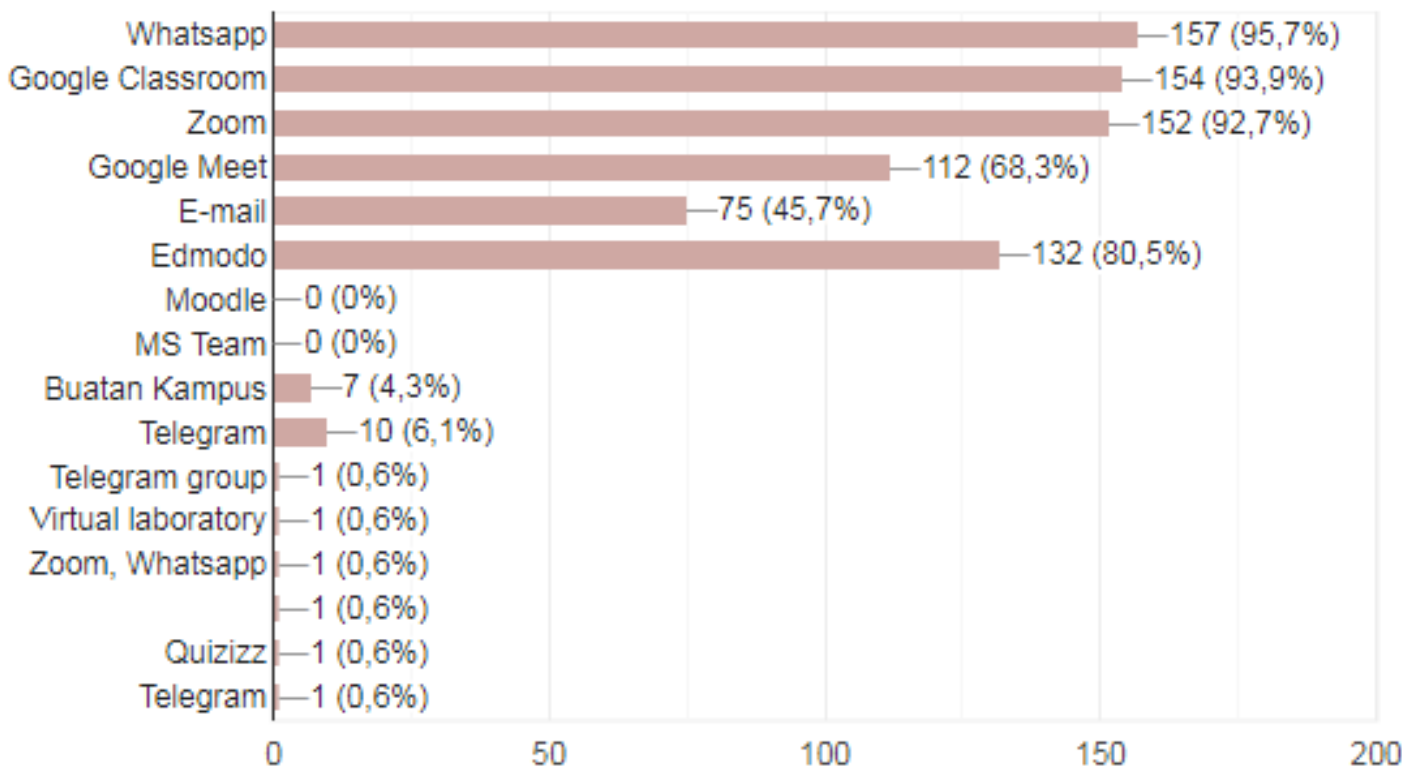

Gambar 4. Platform yang Digunakan oleh Calon Guru Sains dalam Mengikuti Pembelajaran Daring

Berdasarkan Gambar 4 diketahui bahwa platform yang digunakan calon guru sains dalam mengikuti pembelajaran daring dari yang paling banyak bertutut-turut adalah Whatsapp, Google classroom, zoom, edmodo, google meet, dan email. Sedikit dari calon guru yang menggunakan Syarah dan telegram dalam mengikuti pembelajran daring. Whatsapp dan Google classroom merupakan platform pembelajaran daring yang paling disukai oleh mahasiswa (Jamaluddin et al., 2020; Zhafira et al., 2020), baik di Indonesia maupun di luar negeri, contohnya Afrika Selatan. Mahasiswa di Afrika Selatan lebih suka menggunakan platform e-learning informal yang lebih akrab dengan mereka, yaitu WhatsApp (Mpungose, 2020). Whatsapp lebih diminati oleh dosen maupun calon guru sains dibanding Google classroom karena notifikasinya yang lebih fleksibel, sedangkan notifikasi Google classroom masuk ke email. Selain itu, di Whatsapp ada fitur unggah dan unduh gambar dan video yang sangat membantu memudahkan dalam kegiatan pembelajaran. Selain Whatsapp, Google classroom juga diminati karena memang platform untuk pembelajaran, dimana fitur-fiturnya dirancang khusus untuk pembelajaran (Ventayen et al., 2018). Menurut Kumar, Bervell and Osman (2020), sebagian besar institut pendidikan termasuk pendidikan tinggi di Malaysia menggunakan Google Classroom.
Akses sumber materi pembelajaran kini sangat mudah didapat karena berkembang pesatnya teknologi digital (internet). Sesuai konsep pendidikan yang digagas oleh Mendikbud RI yaitu merdeka belajar, peserta didik dapat belajar dari mana saja dan di mana saja. Namun demikian baik pendidik maupun peserta didik memiliki kecenderungan untuk mengakses materi pengayaan pembelajaran dari suatu sumber tertentu terkait sifat sumber tersebut. Terdapat sumber yang bersifat audio, visual, dan audio-visual.

Aspek ke-5 yaitu terkait materi pengayaan. Aspek ini terdiri dari 2 pernyataan. pernyataan pertama terkait penggunaan materi pengayaan dari internet dan pernyataan kedua terkait sumber materi internet yang digunakan. Penggunaan materi pengayaan dari internet dalam pembelajaran daring yang diikuti oleh calon guru sains ditunjukkan pada Gambar 5.
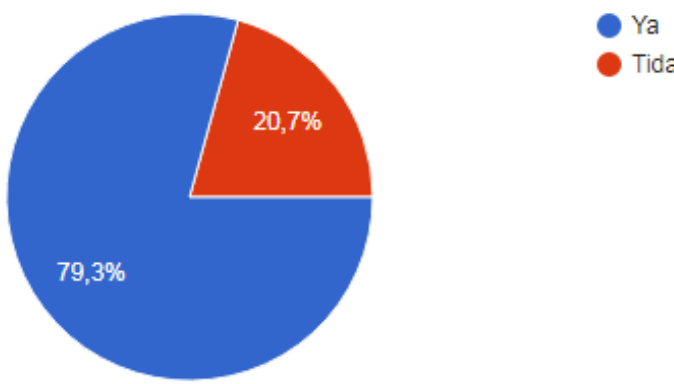
- Tidak

Gambar 5. Penggunaan Materi Pengayaan dari Internet dalam Pembelajaran Daring 
Berdasarkan Gambar 5 diketahui bahwa sebagian besar $(79,3 \%)$ calon guru sains mendapatkan materi pengayaan dari internet dalam pembelajaran sains. Sedangkan sumber materi paling banyak dari YouTube (87\%). YouTube menjadi sumber pembelajaran yang cukup potensial, baik pada pengajaran biologi (Dy et al., 2019), maupun kimia (Elmer \& Mojica, 2019). Selain itu calon guru sains ada yang menggunakan repositori/website perguruan tinggi lain baik dalam negeri dan luar negeri, Khan Academy, dan SPADA. Walaupun SPADA dikembangkan oleh Kemendikbud Indonesia, namun kenyataannya sangat sedikit yang mengakses website tersebut. Kurangnya sosialisasi dan kurang menariknya tampilan dapat menjadi faktor.

Aspek ke-6 adalah format penyampaian materi pembelajaran daring yang diikuti calon guru sains, ditunjukkan oleh Gambar 6.

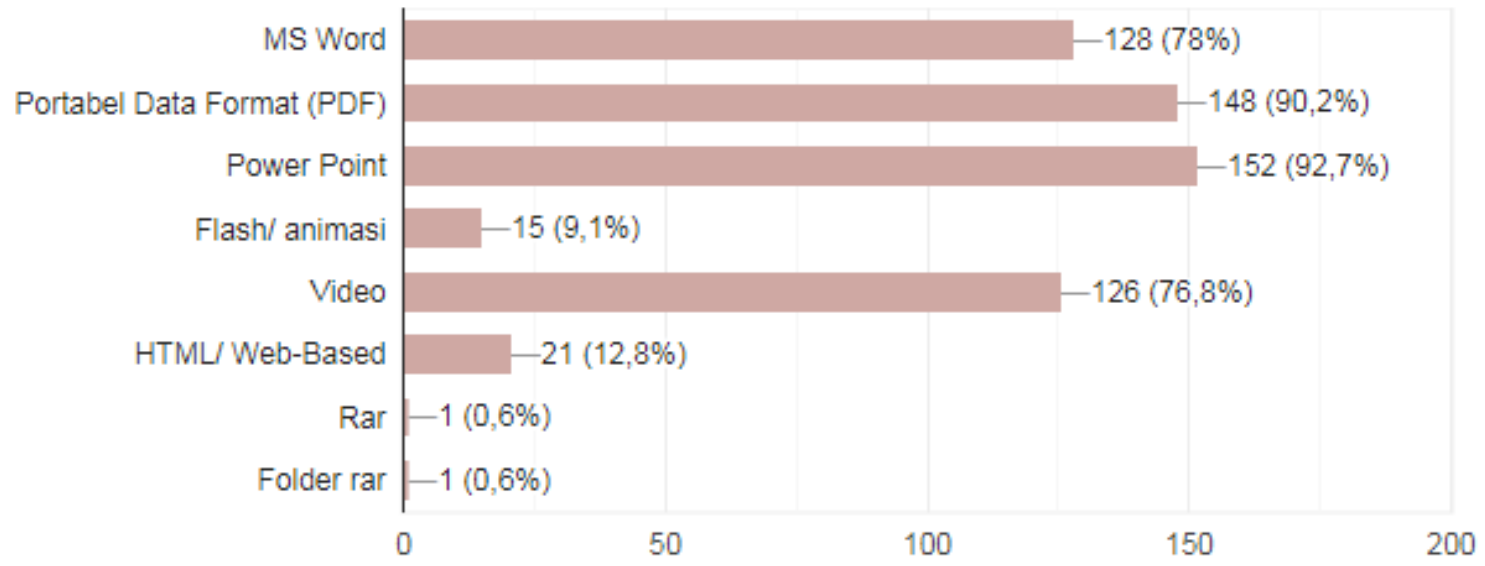

Gambar 6. Format Penyampaian Materi Pembelajaran Daring

Format penyampaian materi yang digunakan oleh dosen dalam pembelajaran daring dari yang paling banyak berturut-turut adalah power point, PDF, MS Word, dan video. Kurang dari $13 \%$ calon guru yang mendapatkan materi dengan format berupa flash/animasi dan HTML/Web-Based. Media power point lebih direkomendasikan dalam penyampaian materi pembelajaran dengan alasan lebih murah, mudah dan hasil video yang tidak lebih buruk dibanding media virtual reality (Leder et al., 2019).
Aspek ke-7 yaitu penggunaan video conference dalam pembelajaran daring yang diikuti oleh calon guru sains terdiri dari 2 (dua) pernyataan. Pernyataan pertama terkait apakah calon guru sains menggunakan video conference dalam pembelajaran daring dan pernyataan kedua terkait jenis video conference yang digunakan. Terkait pernyataan pertama menunjukkan bahwa $97 \%$ calon guru sains menggunakan video conference dalam pembelajaran daring yang diikuti. Sedangkan jenis video conference yang digunakan ditunjukkan pada Gambar 7. 


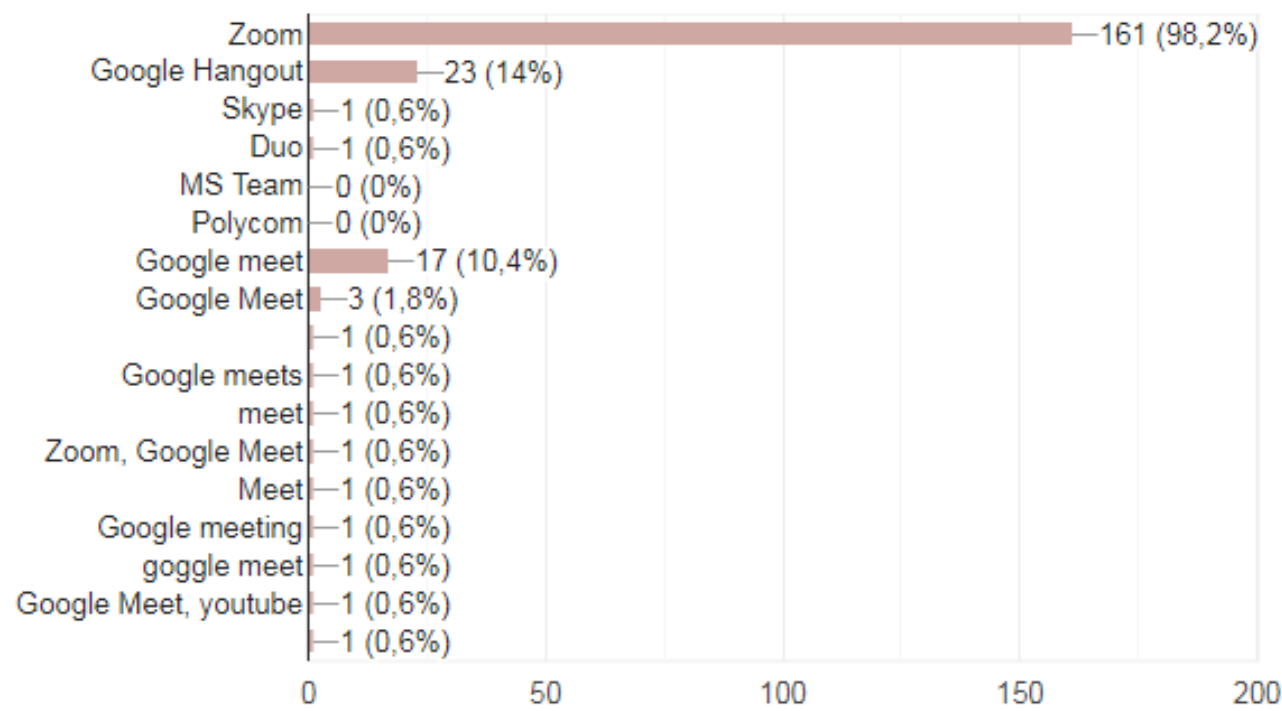

Gambar 7. Jenis Video Conference yang Digunakan Dalam Pembelajaran Daring

Berdasarkan Gambar 7 diketahui bahwa video conference berupa Zoom digunakan oleh hampir seluruh $(97 \%)$ calon guru sains dalam pembelajaran daring. Zoom sangat efektif untuk video conference dalam pembelajaran daring selama Pandemi Covid-19 karena gratis, fleksibel, dan multiplatform serta dapat berbagi files melalui cloud repository populer (DropBox, Microsoft OneDrive, Google Drive, atau Box) (Abdillah, 2020). Selain zoom, 25\% calon guru menggunakan video conference berupa google hangout. Hanya sebagian kecil yang memakai Skype dan Duo.

Aspek ke-8 yaitu keinginan calon guru sains mengikuti pembelajaran daring untuk seterusnya. Aspek ini terdiri dari 2 (dua) pernyataan/pertanyaan. Pernyataan pertama berbunyi: "Jika diperbolehkan, saya lebih suka dan ingin melakukan/mengikuti kuliah secara online seterusnya." dengan alternatif jawaban "ya" dan "tidak". Sedangkan pernyataan kedua berbunyi: "Jika jawaban pada pertanyaan di atas 'Ya', apakah bentuk pembelajaran online yang lebih Anda sukai?" dengan pilihan jawaban "fully online" dan "blended (online dan tatap muka)". Keinginan calon guru sains mengikuti pembelajaran daring untuk seterusnya ditunjukkan pada Gambar 8 dan 9.

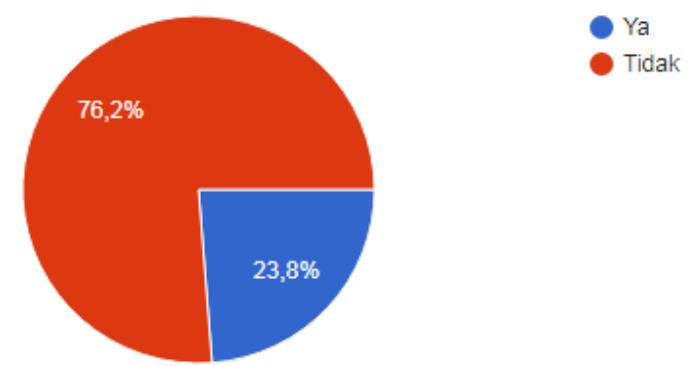

Gambar 8. Keinginan Calon Guru Sains Mengikuti Pembelajaran Daring untuk Seterusnya

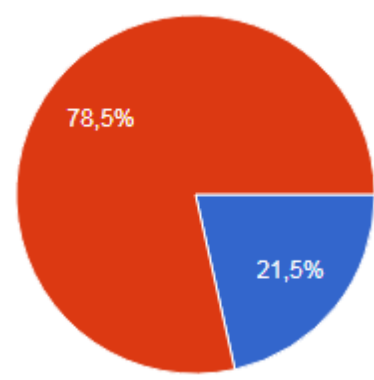

Fully Online

Blended (dengan tatap muka)

Gambar 9. Pilihan Pembelajaran Daring yang Diinginkan

Berdasarkan Gambar 8 diketahui bahwa sebagian besar $(76,2 \%)$ calon guru sains tidak ingin dan tidak suka terus menerus mengikuti pembelajaran secara daring. Sedangkan calon guru sains yang lebih suka terus menerus mengikuti pembelajaran daring sebagian besar $(78,5 \%)$ menginginkan blended learning yang ditunjukkan oleh Gambar 9. Sebagian kecil $(21,5 \%)$ menginginkan sebaliknya (full online). Blended learning (pembelajaran campuran) lebih disukai oleh guru dengan alasan pembelajaran secara online sepenuhnya dianggap kurang dapat 
mengakomodasi seluruh kebutuhan dalam pembelajaran (Zhafira et al., 2020). Dengan adanya pembelajaran tatap muka pada blended learning, interaksi sosial dapat tetap terjadi sehingga peserta didik akan secara langsung memperoleh feedback dari hasil pembelajaran (Anhusadar, 2020).

Aspek ke-9 yaitu pola komunikasi dalam pembelajaran daring yang disukai calon guru sains, ditunjukkan pada Gambar 10.

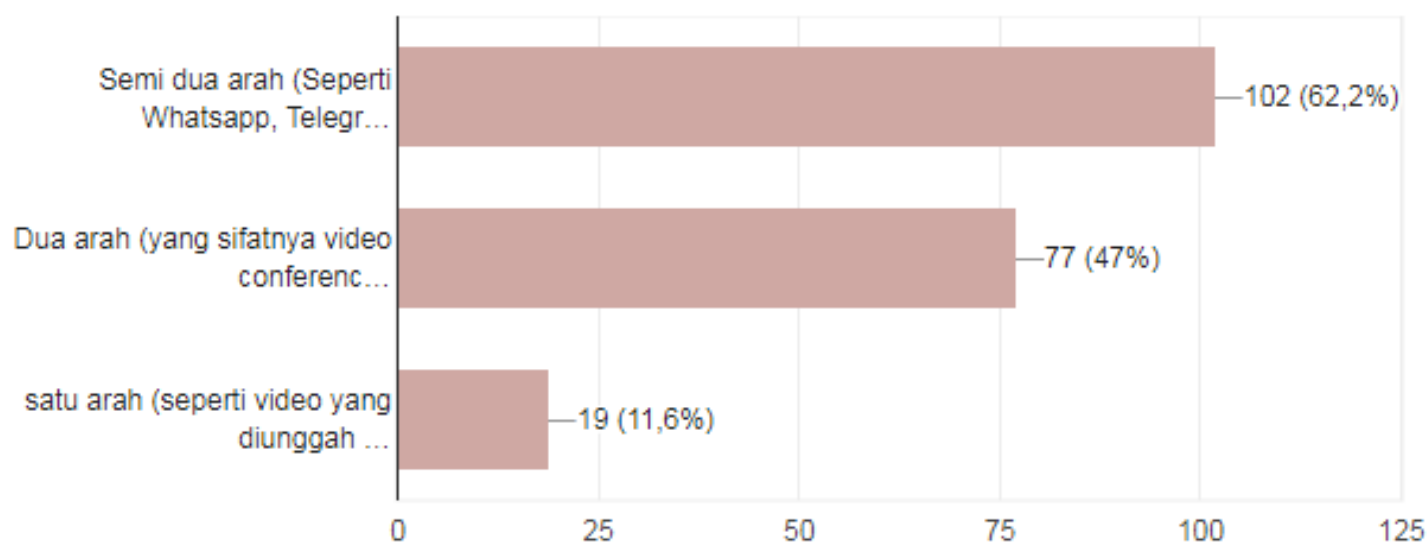

Gambar 10. Pola Komunikasi dalam Pembelajaran Daring yang Disukai

Berdasarkan Gambar 10 diketahui bahwa pola komunikasi yang paling banyak diminati oleh calon guru sains berturut-turut adalah semi dua arah, dua arah, dan satu arah. Hasil tersebut sejalan dengan penelitian Zhafira et al. (2020) yang menyatakan bahwa pola komunikasi yang paling diminati oleh mahasiswa adalah pola semi dua arah.

Aspek ke-10 yaitu praktikum yang dilakukan oleh calon guru sains dalam masa pandemi covid-19, ditunjukkan pada Gambar 11.

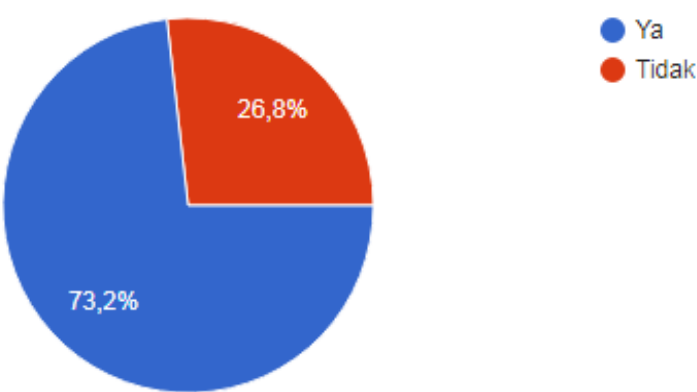

Gambar 11. Praktikum yang Dilakukan

Berdasarkan Gambar 11 diketahui bahwa sebagian besar $(73,2 \%)$ calon guru sains tetap melakukan praktikum pada masa pandemi
Covid-19. Hampir 60\% calon guru sains melakukan praktikum di rumah dan secara virtual. Tidak ada yang melakukan praktikum secara mandiri di laboratorium. Praktikum dilakukan oleh mahasiswa Pendidikan Biologi UIN SGD Bandung dengan menggunakan platform Google Classroom (Suhada et al., 2020). Sedangkan hasil penelitian Jariyah and Tyastirin (2020) menunjukkan bahwa kurangnya kegiatan praktikum yang terlaksana pada masa pandemi Covid-19, sehingga diharapkan dosen membuat rancangan praktikum sedemikian rupa yang bisa dilaksanakan mahasiswa di rumah.

Aspek ke-11 yaitu keterlaksanaan prinsip pendekatan saintifik pada pembelajaran daring yang diikuti calon guru sains. Aspek ini terdiri dari 2 (dua) pernyataan. Pernyataan pertama terkait apakah pembelajaran online yang diikuti mengimplementasikan pendekatan saintifik. $60 \%$ responden menyatakan bahwa pembelajaran online yang diikuti tidak mengimplementasikan pendekatan saintifik. Sedangkan pernyataan kedua terkait prinsip pendekatan saintifik yang kurang terimplementasi, ditunjukkan pada Gambar 12. 


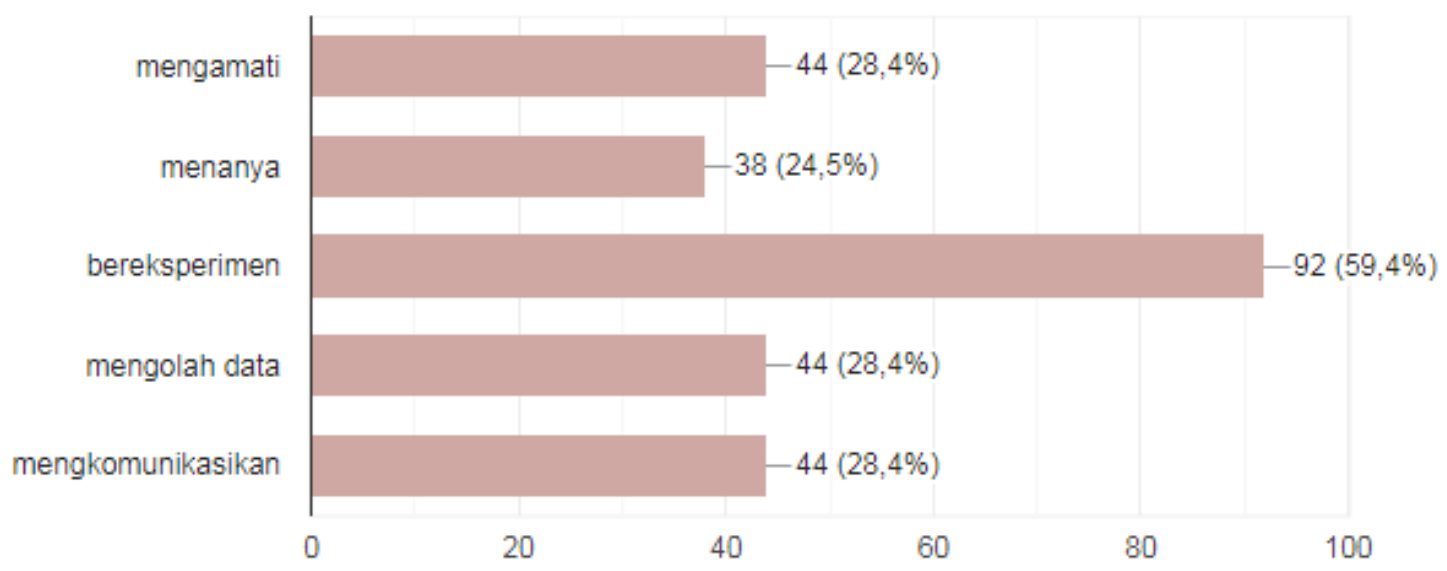

Gambar 12. Keterlaksanaan Prinsip Pendekatan Saintifik pada Pembelajaran Daring

Berdasarkan Gambar 12 diketahui bahwa prinsip pendekatan saintifik yang kurang terimplementasi adalah prinsip bereksperimen. Prinsip yang lain juga kurang berkembang dengan persentase tidak jauh berbeda yaitu sekitar 24,5 sampai dengan 28,4\%. Kegiatan yang mendukung prinsip eksperimen salah satunya adalah praktikum. Penelitian ini sejalan dengan penelitian Jariyah and Tyastirin (2020) yang menunjukkan bahwa kurangnya kegiatan praktikum yang terlaksana pada masa pandemi Covid-19.

Aspek ke-12 yaitu kendala dan manfaat pembelajaran daring. Aspek ini terdiri dari 2 (dua) pernyataan. Pernyataan pertama terkait kendala yang dihadapi calon guru sains dalam pembelajaran daring selama masa pandemi Covid-19 dan pernyataan kedua terkait manfaat pembelajaran daring . Kendala terbesar calon guru sains di Tanjungpinang dalam mengikuti pembelajaran daring adalah terbatasnya jaringan/signal internet dan paket/kuota data internet. Kendala jaringan dan kuota internet juga ternyata dirasakan juga oleh calon guru sains UIN Sunan Gunung Djati Bandung (Farida et al., 2020; Jamaluddin et al., 2020). Selain itu calon guru sains juga kurang memahami materi dibanding pembelajaran luring dan terbebani oleh tugas yang banyak. Sebagian kecil mengaku waktu perkuliahan yang tidak sesuai dengan jadwal, keterbatasan listrik, diskusi yang kurang efektif baik mahasiswa dengan dosen maupun antar mahasiswa, susah atau ribet menggunakan aplikasi, dan susah melakukan praktikum.

Sebagian besar calon guru sains di Tanjungpinang merasakan manfaat pembelajaran daring antara lain: efisien dalam hal waktu, literasi teknologi digital meningkat, terhindar dari Covid-19, dapat belajar di mana saja, dan hemat biaya transportasi. Ada juga yang merasakan dapat lebih dekat dengan keluarga, waktu lebih fleksibel, proses belajar dan mengajar lebih praktis, dapat lebih cepata mengerjakan tugas, lebih seru, dan lebih mandiri terhadap diri sendiri. Beberapa keuntungan pembelajaran daring antara lain: memungkinkan siswa belajar sesuai dengan kecepatannya sendiri, dapat mengakses informasi lebih luas sehingga meningkatkan pengetahuan, hemat karena tidak perlu mengeluarkan biaya untuk transportasi, lebih fleksibel terkait waktu dan tempat, serta siswa berpeluang lebih besar aktif dalam forum diskusi karena dapat menghilangkan hambatan seperti ketakutan untuk berbicara (Arkorful \& Abaidoo, 2015).

Aspek ke-13 yaitu kesan dan pendapat tentang pembelajaran daring selama masa pandemi Covid-19. Kesan calon guru sains dalam pembelajaran daring yang diikutinya beragam, ada yang memiliki kesan baik, cukup baik, dan kurang baik. Calon guru sains yang memiliki kesan baik memberikan alasan antara lain: kebijakan kampus yang mengijinkan menggunakan beberapa aplikasi; kampus memberikan paket data kepada mahasiswa; merasakan lebih aman dari Covid-19; lebih merasakan manfaat teknologi di pendidikan; dapat belajar kapan saja dan di mana saja; dan mahasiswa dapat lebih kreatif. Perkuliahan daring dapat kreativitas mahasiswa (Husamah \& Rahardjanto, 2018).

Calon guru sains yang memiliki kesan kurang baik memberikan alasan antara lain: terlalu banyak tugas; ada beberapa mahasiswa yang tidak pernah berpartisipasi dalam diskusi atau tidak memperhatikan dosen saat menjelaskan materi. Selain itu mahasiswa juga kurang memahami materi, terutama untuk materi yang berkaitan dengan perhitungan. Hal tersebut sejalan dengan penelitian Farida et al. 
(2020) tentang pengalaman calon guru kimia dalam pembelajaran sistem daring selama masa Pandemi Covid-19 yang menyatakan bahwa calon guru kimia mengalami kesulitan pada konten kimia yang berkaitan dengan perhitungan, reaksi-reaksi dan representasi submikroskopik.

Pendapat calon guru sains terhadap pembelajaran daring antara lain: agar dosen memandu pembelajara secara lebih inovatif; sebaiknya seluruh mata kuliah menggunakan platform yang sama; agar pembelajaran daring dilakukan menggunakan aplikasi yang bisa dijangkau oleh seluruh mahasiswa; tidak mengganti pembelajaran daring dengan tugas; adanya bantuan paket data yang lebih banyak; dosen memberikan toleran kepada peserta didik yang terkendala jaringan; pihak kampus memberikan kebijakan terkait keringanan dalam membayar UKT; agar pembelajaran daring dilakukan tepat sesuai jadwal. Hal ini sebagaiman ditegaskan oleh beberapa artikel penelitian sebelumnya (Jariyah \& Tyastirin, 2020; Lukitasari et al., 2019; Maryuningsih et al., 2019)

\section{Simpulan dan Saran}

\section{Simpulan}

Hampir seluruh calon guru sains mengikuti pembelajaran daring dari rumah dengan menggunakan perangkat smartphone dan platform pembelajaran berupa whatsapp dan google classroom, serta video conference yaitu zoom. Sebagian besar mendapatkan materi pengayaan dari internet yaitu YouTube, sedangkan format penyampaian materi yang digunakan oleh dosen yang paling banyak berturut-turut adalah power point, PDF, MS Word, dan video. Sebagian besar calon guru sains tidak ingin dan tidak suka terus menerus mengikuti pembelajaran secara daring, namun demikian, mereka tetap melakukan praktikum yang dilakukan secara mandiri di rumah dan juga secara virtual. Menurut sebagian besar calon guru sains, pembelajaran daring yang diikutinya kurang sesuai dengan prinsip pendekatan saintifik karena kemampuan bereksperimen calon guru sains kurang berkembang. Walaupun sistem daring dapat dijadikan solusi, kendala seperti terbatasnya jaringan dan paket data internet menjadi dua aspek besar yang mengganggu pembelajaran daring. Namun demikian, calon guru sains merasakan manfaat pembelajaran daring antara lain efisien dalam hal waktu, literasi teknologi digital meningkat, dan terhindar dari Covid-19.

\section{Saran}

Pembelajaran daring hendaknya dilakukan dengan memahami platform dan aplikasi yang lebih sering digunakan oleh calon guru sains, agar pembelajaran dapat berjalan lebih optimal. Jika kondisi sudah memungkinkan, calon guru sains menginginkan pembelajaran secara blended learning, karena mereka mengalami kendala dan tidak terbiasa dengan pembelajaran daring full online. Walaupun pembelajaran dilakukan dengan daring, hendaknya praktikum tetap dilakukan dapat secara mandiri ataupun virtual. Pembelajaran daring selanjutnya hendaknya tetap memperhatikan keterlaksanaan prinsip pendekatan saintifik.

\section{Ucapan Terima Kasih}

Penulis mengucapkan terima kasih kepada LP3M dan Program Studi Pendidikan Biologi dan Kimia UMRAH yang telah mendukung terlaksananya kegiatan penelitian ini. Selanjutnya penulis juga mengucapkan terima kasih kepada para calon guru di Program Studi Pendidikan Biologi dan Kimia UMRAH yang telah bersedia menjadi responden.

\section{Daftar Pustaka}

Abdillah, L. A. (2020). Online learning menggunakan zoom teleconference. http://eprints.binadarma.ac.id/4162/2/Abdi llah2020 [Online Learning Menggunakan Zoom Teleconference] 2020415.pdf

Anhusadar, L. O. (2020). Persepsi mahasiswa PIAUD terhadap kuliah online di masa pandemi covid 19. Kindergarten: Journal of Islamic Early Childhood Education, $3(1)$, 44-58. https://doi.org/http://dx.doi.org/10.24014/ kjiece.v3i1.9609

Arkorful, V., \& Abaidoo, N. (2015). The pedagogical functions of arts and culturalheritage education with ICTs in museums. International Journal of Instructional Technology and Distance Learning, 12(1), 29-42.

Baguma, R., Bagarukayo, E., Namubiru, P., Brown, C., \& Mayisela, T. (2019). Using whatsapp in teaching to develop higher 
order thinking skills-a literature review using the activity teory lens. International Journal of Education and Development Using Information and Communication Technology (IJEDICT), 15(2), 98-116.

Dash, S. (2019). Google classroom as a learning management system to teach biochemistry in a medical school. Biochemistry and Molecular Biology Education, 47(4), 404-407. https://doi.org/10.1002/bmb.21246

de Jong, P. G. M., Pickering, J. D., Hendriks, R. A., Swinnerton, B. J., Goshtasbpour, F., \& Reinders, M. E. J. (2020). Twelve tips for integrating massive open online course content into classroom teaching. Medical Teacher, 42(4), 393-397. https://doi.org/10.1080/0142159X.2019.1 571569

Dy, A. J., Aurand, E. R., \& Friedman, D. C. (2019). YouTube resources for synthetic biology education. Synthetic Biology, 4(1), $1-4$.

https://doi.org/10.1093/synbio/ysz022

Elmer, \& Mojica, R. E. (2019). CHEMTERTAINMENT: Using video clips from movies, television series, and youtube to enhance the teaching and learning experience of an introductory chemistry lecture class [Chapter]. ACS Symposium Series, 1325, 21-34. https://doi.org/10.1021/bk-20191325.ch002

Faramarzi, S., Tabrizi, H. H., \& Chalak, A. (2019). Telegram: An instant messaging application to assist distance language learning. Teaching English with Technology, 19(1), 132-147.

Farida, I., Sunarya, R. R., Aisyah, R., \& Helsy, I. (2020). Pembelajaran kimia sistem daring di masa pandemi covid-19 bagi generasi z. KTI UIN Sunan Gunung Djati, $1-11$.

Gugus Tugas COVID-19 KEPRI. (2020). Statistik data kasus covid-19 di tanjungpinang. 14 Juni 2020. https://corona.kepriprov.go.id/data.phtml

Hamutoglu, N. B., Gemikonakli, O., \& Gezgin, D. M. (2008). A study of the effectiveness of edmodo on preservice classroom teachers' views of web-assisted collaborative learning environments, sense of classroom community, and perceived learning nazire. Science Education International, 30(2), 128-137.

Hermansyah, F. I. (2020). Pengambilan kebijakan oleh swedia dan indonesia terhadap pandemi covid-19. Journal of Virology, 1-14.

Husamah, H., \& Rahardjanto, A. (2018). OIDDE-PjBL learning model: Problemsolving skillsand product creativity for study of biology prospective teachers. The 3rd Progressive and Fun Education International Seminar ISBN:, August, 4151.

Jamaluddin, D., Ratnasih, T., Gunawan, H., \& Paujiah, E. (2020). Pembelajaran daring masa pandemik covid-19 pada calon guru: Hambatan, solusi dan proyeksi. Karya Tulis Ilmiah UIN Sunan Gunung Djjati Bandung, 1-10. http://digilib.uinsgd.ac.id/30518/

Jariyah, A., \& Tyastirin, E. (2020). The biology learning processes and constraints in the covid-19 pandemic period: analysis of student responses. 4(2), 183-196.

Kemdikbud. (2020). Surat edaran nomor 4 tahun 2020 tentang pelaksanaan pendidikan dalam masa darurat corona virus disease (covid-19). 24 Maret 2020. https://www.kemdikbud.go.id/main/blog/2 020/03/mendikbud-terbitkan-se-tentangpelaksanaan-pendidikan-dalam-masadarurat-covid19

Khoir, H. M., Murtinugraha, R. E., \& Musalamah, S. (2020). Pengembangan media pembelajaran e-learning berbasis moodle pada mata kuliah metodologi penelitian. Jurnal Pendidikan Teknik Sipil, 9(1), 54-60. https://doi.org/10.1017/CBO97811074153 24.004

Kumar, J. A., \& Bervell, B. (2019). Google Classroom for mobile learning in higher education: Modelling the initial perceptions of students. Education and Information Technologies, 24(2), 17931817. https://doi.org/10.1007/s10639-01809858-z 
Kumar, J. A., Bervell, B., \& Osman, S. (2020). Google classroom: insights from Malaysian higher education students' and instructors' experiences. Education and Information Technologies Volume, 25, 4175-4195.

https://link.springer.com/article/10.1007\% 2Fs10639-020-10163-x

Leder, J., Horlitz, T., Puschmann, P., Wittstock, V., \& Schütz, A. (2019). Comparing immersive virtual reality and powerpoint as methods for delivering safety training: Impacts on risk perception, learning, and decision making. Safety Science, 111(2019), 271-286. https://doi.org/10.1016/j.ssci.2018.07.021

Lemay, D. J., \& Doleck, T. (2020). Predicting completion of massive open online course (MOOC) assignments from video viewing behavior. Interactive Learning Environments, $\quad 0(0), \quad 1-12$. https://doi.org/10.1080/10494820.2020.17 46673

Lukitasari, M., Purnamasari, I., Utami, S., \& Sukri, A. (2019). Blended-Problem-Based Learning: How its impact on students' critical thinking skills? JPBI (Jurnal Pendidikan Biologi Indonesia), 5(3), 425434.

https://doi.org/10.22219/jpbi.v5i3.10048

Mahzoun, F. E., \& Zohoorian, Z. (2019). Employing telegram application: Learners' attitude, vocabulary learning, and vocabulary delayed retention. European Journal of Foreign Language Teaching, 4(1), 151-165. https://doi.org/10.5281/zenodo.2651380

Maryuningsih, Y., Hidayat, T., Riandi, R., \& Rustaman, N. (2019). Developing Gen$21 \mathrm{cs}$ on smartphone to cultivate the $21 \mathrm{st}-$ century skills on biology teacher candidates. JPBI (Jurnal Pendidikan Biologi Indonesia), 5(3), 415-424. https://doi.org/10.22219/jpbi.v5i3.9714

Mpungose, C. B. (2020). Is Moodle or WhatsApp the preferred e-learning platform at a South African university? First-year students' experiences. Education and Information Technologies, 25 , 927-941. https://link.springer.com/article/10.1007/s
10639-019-10005-5

Nagaletchimee, A. (2015). Using whatsapp to extend learning in a blended classroom environment. Teaching English with Technology, 19(1), 3-20.

Ngibad, K., Herawati, D., Ekawati, E. R., \& Pradana, M. S. (2020). Pelatihan Elearning berbasis Moodle untuk DosenDosen Fakultas Ilmu Kesehatan Universitas Maarif Hasyim Latif Sidoarjo. Darmabakti Jurnal Pengabdian Dan Pemberdayaan Masyarakat, 1(1), 13-18.

Onah, D. F. O., \& Sinclair, J. E. (2017). Assessing self-regulation of learning dimensions in a stand-alone mooc platform. International Journal of Engineering Pedagogy (iJEP), 7(2), 4-21. https://doi.org/10.3991/ijep.v7i2.6511

Rahaded, U., Puspitasari, E., \& Hidayati, D. (2020). The impact of whatsapp toward uad undergraduate students' behavior in learning process. International Journal of Educational Management and Innovation, $1(1)$, $55-68$. https://doi.org/10.12928/ijemi.v1i1.1515

Rahmad, R., Wirda, A. M., Berutu, N., Lumbantoruan, W., \& Sintong, M. (2019). Google classroom implementation in Indonesian higher education. Journal of Physics: Conference Series, 1175(1), 1-6. https://doi.org/10.1088/1742$6596 / 1175 / 1 / 012153$

Suhada, I., Kurniati, T., Pramadi, A., \& Listiawati, M. (2020). Pembelajaran daring berbasis google classroom mahasiswa pendidikan biologi pada masa wabah covid -19 . http://digilib.uinsgd.ac.id/30584/.

UMRAH. (2020). Sistem kerja pegawai universitas maritim raja ali haji dalam tatanan normal baru. 15 Juni 2020. https://umrah.ac.id/wpcontent/uploads/2020/06/edaran-tatanannormal-baru-UMRAH-2020.pdf

Ventayen, R. J. M., Estira, K. L. A., Guzman, M. J. De, Cabaluna, C. M., \& Espinosa, N. N. (2018). Usability evaluation of google classroom: basis for the adaptation of gsuite e-learning platform software management view project data analysis 
view project. Asia Pacific Journal of Education, Arts and Sciences, 5(1), 47-51.

Wicaksana, E. J., Atmadja, P., Lestari, W., Tanti, L. A., \& Odrina, R. (2020). Efektivitas pembelajaran menggunakan moodle terhadap motivasi dan minat bakat. EduTeach: Jurnal Edukasi Dan Teknologi Pembelajaran, 1(2), 117-124.

World Health Organization (WHO). (2020). Situasi penyebaran penyakit coronavirus (covid-19). 14 Juni 2020 07:00 GMT+7. https://www.who.int/emergencies/diseases /novel-coronavirus-2019
Zainudin, Z., \& Pambudi, B. (2019). Developing critical thinking skills-based learning set of basic physics subject using edmodo in android platform. Jurnal Pendidikan Fisika Indonesia, 15(1), 1423. https://doi.org/10.15294/jpfi.v15i1.14350

Zhafira, N. H., Ertika, Y., \& Chairiyaton. (2020). Persepsi mahasiswa terhadap perkuliahan daring sebagai sarana pembelajaran selama masa karantina covid-19. Jurnal Bisnis Dan Kajian Strategi Manajemen, 4(1), 37-45. 